\title{
BIOCHEMICAL CHANGES AND OSTEOSCLEROSIS AFTER SULPHAMEZATHINE THERAPY IN IDIOPATHIC HYPERCALCAEMIA OF INFANCY
}

\author{
BY \\ L. C. HARRIS \\ From the Children's Department, the Royal Victoria Infirmary, and the Babies' Hospital, Newcastle upon Tyne
}

(RECEIVED FOR PUBLICATION FEBRUARY 9, 1954)

In communications to the British Paediatric Association in 1952, Lightwood and Payne described a group of 10 infants between the ages of 3 and 7 months presenting with anorexia, vomiting, failure to thrive, constipation and sometimes polyuria and polydipsia. They had hypercalcaemia, azotaemia and normal alkali reserves and in two of them radiographs showed nephrocalcinosis. There was no obvious cause for the hypercalcaemia, such as hyperparathyroidism or hypervitaminosis $\mathrm{D}$, so they regarded it as a new syndrome. Fanconi and Girardet (1952) and Schlesinger, Butler and Black (1952) described two cases with hypercalcaemia and bone changes similar to those described in this communication. In the case described by Fanconi and Girardet hyperphosphataemia was present and the calcium-phosphorus product considerably raised. Creery (1953) described a case of hypercalcaemia in infancy and this child had osteosclerosis and at times a very high serum calcium-phosphorus product, though the period of observation was short. These and other observations have awakened interest in what may be a disease hitherto undescribed, with a group of clinical phenomena the pathogenesis of which is not yet clear.

I have studied four infants with the same syndrome at the Royal Victoria Infirmary and the Babies Hospital in Newcastle. Three of them had urinary tract infections, which are very frequently but not invariably present in this illness, and were treated with sulphamezathine as well as other drugs in order to attempt to control the extremely resistant infections. The purpose of this paper is threefold: first, to describe the toxic effects of sulphamezathine in three of these children, with special reference to the bone changes in one case; secondly, to correlate these bone changes with changes in the serum calcium-phosphorus products; and thirdly, to emphasize the clinical picture, which may lead a practitioner to suspect the disease so that treatment with sulphamezathine can be avoided.

The biochemical changes in the following three cases are given in Table 1.

\section{Case Histories}

Case 1. J.W. was a first child, delivered by forceps after a full-term, normal pregnancy. His birth weight was $7 \mathrm{lb} .6 \mathrm{oz}$., he had been artificially fed from birth and had accepted solid feeds from $5 \frac{1}{2}$ months of age. He had refused cod liver oil and had had no excess of vitamin D. He thrived until the age of 7 months when he began to vomit, became markedly constipated and lost weight.

He was admitted to hospital at the age of 8 months, weighing $16 \mathrm{lb} .4 \mathrm{oz}$. He was a miserable infant with a greyish colour, who tended to lie still, though he displayed some interest in his surroundings. He was moderately dehydrated and hypotonic, with soft muscles, brisk reflexes and palpable faecal masses in the colon.

Counting pus cells per c.mm. in fresh uncentrifuged specimens of urine (Stansfeld and Webb, 1953) pyuria of up to 420 cells per c.mm. was found and, after two negative cultures, coliform organisms were isolated from the urine on two occasions. Hypercalcaemia and azotaemia were present and the alkali reserve was normal. The packed cell volume and haemoglobin were normal.

The infant became more contented as hydration improved. A course of streptomycin reduced the pyuria only slightly, but after withdrawing the drug it increased and vomiting started again. Sulphamezathine was then given orally and was continued for two weeks, starting with $2 \mathrm{~g}$. daily in four divided doses and reducing the dose to $1 \mathrm{~g}$. daily after six days. At the same time $2 \mathrm{~g}$. sodium citrate was given daily for the first eight days. In two weeks, from a level of $74 \mathrm{mg}$. per $100 \mathrm{ml}$. the blood urea had risen to $246 \mathrm{mg}$. and the serum calcium level had fallen from $15.9 \mathrm{mg}$. to $12.8 \mathrm{mg}$. per $100 \mathrm{ml}$. Neither haematuria not crystalluria was present and the blood urea returned to $73 \mathrm{mg}$. per $100 \mathrm{ml}$. in 13 days.

At 11 months of age, on a fluid intake of $1 \mathrm{oz}$. per $\mathbf{l b}$. 
TABLE 1

BIOCHEMICAL INVESTIGATIONS

\begin{tabular}{|c|c|c|c|c|c|c|c|c|c|}
\hline \multirow{2}{*}{ Date } & \multicolumn{3}{|c|}{$\begin{array}{l}\text { Serum Protein } \\
\text { (g. per } 100 \text { ml.) }\end{array}$} & \multirow{2}{*}{$\begin{array}{l}\text { Serum } \\
\text { Calcium } \\
\text { (mg. per } \\
100 \text { ml.) }\end{array}$} & \multirow{2}{*}{$\begin{array}{c}\text { Plasma } \\
\text { Phosphorus } \\
\text { (mg. per } \\
\text { 100 ml.) } \\
\end{array}$} & \multirow{2}{*}{$\begin{array}{l}\text { Alkali } \\
\text { Reserve } \\
\text { mEq./1.) }\end{array}$} & \multirow{2}{*}{$\begin{array}{c}\text { Blood } \\
\text { Urea } \\
\text { (mg. per } \\
100 \mathrm{ml} . \text { ) }\end{array}$} & \multirow{2}{*}{$\begin{array}{c}\text { Serum } \\
\text { Chloride } \\
\text { (m.Eq. } \\
\text { per 1.) }\end{array}$} & \multirow{2}{*}{$\begin{array}{l}\text { Alkaline Phos- } \\
\text { phatase Units } \\
\text { (Jenner and } \\
\text { Kay) }\end{array}$} \\
\hline & Total & Albumin & Globulin & & & & & & \\
\hline 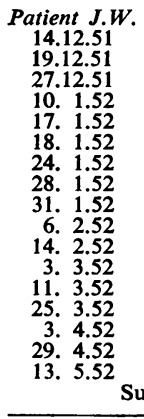 & $\begin{array}{c}4.9 \\
7 \cdot 2 \\
6.3 \\
7.0 \\
6.9 \\
7.0 \\
7.5 \\
\\
5.4 \\
6.3 \\
\text { hamezat }\end{array}$ & $\begin{array}{c}5 \cdot 0 \\
\\
3 \cdot 2 \\
5 \cdot 2 \\
4.9 \\
5 \cdot 5 \\
5.0 \\
6.0 \\
6 \cdot 1 \\
\\
5 \cdot 3 \\
\text { ee started o } \\
\end{array}$ & $\begin{array}{l}1 \cdot 7 \\
2.0 \\
1.4 \\
1.5 \\
1.9 \\
1.5 \\
1.4\end{array}$ & $\begin{array}{l}15 \cdot 9 \\
14 \cdot 7 \\
13 \cdot 2 \\
13 \cdot 1 \\
15 \cdot 9 \\
12 \cdot 8 \\
12 \cdot 7 \\
12 \cdot 3 \\
13 \cdot 3 \\
14 \cdot 3 \\
15 \cdot 6 \\
13 \cdot 6 \\
12 \cdot 6 \\
10 \cdot 5 \\
10 \cdot 3\end{array}$ & $\begin{array}{l}6 \cdot 0 \\
4 \cdot 7\end{array}$ & $\begin{array}{l}23 \cdot 8 \\
24 \cdot 5 \\
26 \cdot 8 \\
29 \cdot 5 \\
22 \cdot 5 \\
21 \cdot 6 \\
21 \cdot 6 \\
26 \cdot 2 \\
26 \cdot 0 \\
23.4 \\
20.8 \\
21.0 \\
25.6 \\
24 \cdot 2\end{array}$ & $\begin{array}{r}80 \\
82 \\
40 \\
74 \\
246 \\
147 \\
72 \\
72 \\
82 \\
74 \\
47 \\
72 \\
66 \\
45 \\
43\end{array}$ & $\begin{array}{r}107 \cdot 2 \\
111 \cdot 0 \\
100 \cdot 9 \\
102 \cdot 0 \\
98 \cdot 9 \\
107 \cdot 0 \\
98 \cdot 4 \\
103 \cdot 2 \\
110 \cdot 8 \\
104 \cdot 9 \\
102 \cdot 9\end{array}$ & $11 \cdot 9$ \\
\hline 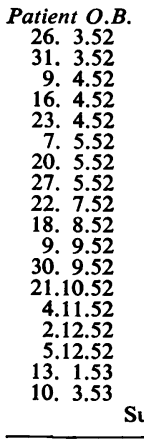 & $\begin{array}{l}6.3 \\
5.7 \\
6.3 \\
5.9 \\
6.9 \\
6.6 \\
6.9 \\
6.3 \\
6.8 \\
6.0 \\
6.2 \\
6.0 \\
\\
6.9 \\
6.5 \\
7.5 \\
8.3 \\
\text { hamezat } \\
\end{array}$ & $\begin{array}{l}4 \cdot 8 \\
4 \cdot 9 \\
4 \cdot 6 \\
5 \cdot 4 \\
5 \cdot 3\end{array}$ & $\begin{array}{l}1.8 \\
2.0 \\
1.7 \\
1.4 \\
0.9\end{array}$ & $\begin{array}{l}13.2 \\
14.1 \\
14.4 \\
13.4 \\
12.4 \\
11.8 \\
13.3 \\
13.1 \\
12.0 \\
10.5 \\
10.5 \\
11.0 \\
10.4 \\
10.6 \\
13.2 \\
9.6 \\
10.6 \\
11.4\end{array}$ & $\begin{array}{l}3 \cdot 8 \\
3 \cdot .7 \\
4 \cdot 0 \\
4 \cdot 1 \\
3 \cdot 4 \\
3 \cdot 3 \\
4 \cdot 9 \\
2 \cdot 8 \\
6 \cdot 4 \\
4 \cdot 9 \\
4 \cdot 7 \\
4 \cdot 7 \\
5 \cdot 0 \\
4 \cdot 6\end{array}$ & $\begin{array}{l}22.5 \\
19.4 \\
20.1 \\
19.6 \\
17.8 \\
20.4 \\
19.3 \\
20.4 \\
18.9 \\
19.1 \\
25.1 \\
23.0 \\
19.5 \\
21.2 \\
13.9 \\
20.8\end{array}$ & $\begin{array}{l}85 \\
45 \\
48 \\
64 \\
66 \\
55 \\
65 \\
57 \\
54 \\
19 \\
40 \\
30 \\
29 \\
37 \\
45 \\
38 \\
37\end{array}$ & $\begin{array}{l}116 \cdot 7 \\
100 \cdot 2 \\
108 \cdot 0 \\
110 \cdot 8 \\
112 \cdot 4 \\
108 \cdot 5 \\
109 \cdot 6 \\
105 \cdot 8 \\
107 \cdot 7 \\
111 \cdot 2 \\
103 \cdot 9\end{array}$ & $\begin{array}{l}12.4 \\
16.7\end{array}$ \\
\hline 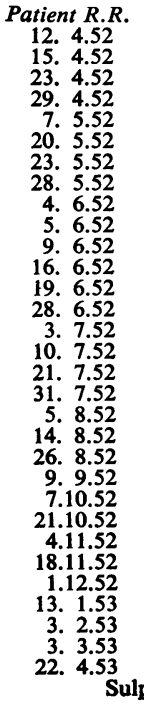 & $\begin{array}{l}6.0 \\
7.4 \\
5.4 \\
5.7 \\
6.6 \\
6.0 \\
6.5 \\
6.0 \\
6.9 \\
6.9 \\
5.7 \\
7.5 \\
6.3 \\
6.8 \\
6.6 \\
5.7 \\
5.6 \\
5.7 \\
7.2 \\
7.5 \\
6.5 \\
6.0 \\
7.4\end{array}$ & $\begin{array}{l}4 \cdot 6 \\
4.9 \\
4 \cdot 2 \\
4 \cdot 3 \\
4 \cdot 2 \\
5 \cdot 2 \\
5 \cdot 2 \\
5 \cdot 4 \\
4 \cdot 0 \\
4 \cdot 3 \\
4 \cdot 4 \\
4.8 \\
\\
4 \cdot 6 \\
6.0\end{array}$ & $\begin{array}{l}1.4 \\
1.6 \\
1.8 \\
2.6 \\
1.5 \\
1.1 \\
1.2 \\
1.7 \\
1.3 \\
1.3 \\
2.4 \\
\\
1.4 \\
1.4\end{array}$ & $\begin{array}{l}14 \cdot 1 \\
17.4 \\
10 \cdot 2 \\
11.8 \\
15.2 \\
17.1 \\
15.0 \\
15.2 \\
9.9 \\
9.97 \\
12.9 \\
14.0 \\
13.6 \\
13.2 \\
12.6 \\
12.8 \\
12.8 \\
12.4 \\
12.8 \\
14 \cdot 2 \\
12.8 \\
13.0 \\
14.3 \\
13.7 \\
13.9 \\
14.4 \\
11.5 \\
13.4 \\
11.8 \\
13.6 \\
13.2\end{array}$ & $\begin{array}{l}5.1 \\
3.5 \\
5.3 \\
4.3 \\
5.7 \\
2.7 \\
10.7 \\
13.4 \\
8.7 \\
8.2 \\
7.8 \\
5.8 \\
6.1 \\
9.0 \\
6.9 \\
7.5 \\
7.1 \\
4.3 \\
7.4 \\
7.8\end{array}$ & $\begin{array}{l}32.4 \\
32.4 \\
24.7 \\
25.6 \\
25.3 \\
25.6 \\
25.6 \\
22.5 \\
18.2 \\
17.8 \\
28.5 \\
22.6 \\
27.8 \\
23.5 \\
24.4 \\
14.9 \\
19.5 \\
27.7 \\
22.6 \\
22.5 \\
17.4 \\
21.2 \\
16.1\end{array}$ & $\begin{array}{c}76 \\
57 \\
50 \\
70 \\
82 \\
73 \\
76 \\
42 \\
\\
\\
171 \\
105 \\
154 \\
93 \\
108 \\
142 \\
136 \\
122 \\
116 \\
110 \\
115 \\
54 \\
83 \\
91 \\
71 \\
107 \\
85 \\
83 \\
76 \\
76\end{array}$ & 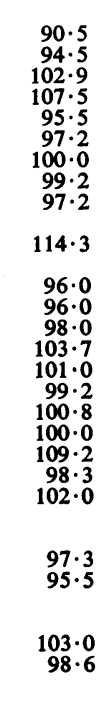 & $\begin{array}{r}11 \cdot 8 \\
11 \cdot 9 \\
9 \cdot 1 \\
15 \cdot 1 \\
16 \cdot 4\end{array}$ \\
\hline
\end{tabular}


for 12 hours, the specific gravity of eight specimens of urine did not exceed 1,010 . By $11 \frac{1}{2}$ months the pyuria had diminished to 63 cells per c.mm. and two urinary cultures were sterile. Though it was still necessary to force the baby to take fluids by mouth he began to gain weight well and by 13 months of age the serum calcium and blood urea had fallen to normal levels. Apart from a mild hypochromic anaemia, which responded well to iron therapy, he continued to thrive and at 15 months of age weighed $23 \mathrm{lb} .8 \mathrm{oz}$. No clinical abnormalities were present and he was still perfectly well when last seen at 1 year 11 months. At this time an early morning specimen of urine had a specific gravity of 1,023 .

Case 2. O.B., a fifth child, she had been born normally after a full-term, normal pregnancy, her birth weight being $6 \mathrm{lb}$. When she was admitted to hospital at the age of 9 months she had never been breast fed and had had no excess of vitamin D. Four weeks before her admission she had been treated at home with a sulphonamide for a respiratory infection with vomiting, which lasted three to four days. Four days before admission she again began to vomit and to refuse solid food, preferring clear fluids. She had become pale and fretful.

On examination, she was a small infant with a pale skin, weighing $9 \mathrm{lb} .11 \mathrm{oz}$. She had soft muscles but her tendon reflexes were very brisk. Pyuria was present intermittently and coliform organisms were isolated from the second and third catheter specimens of urine. It was found that she had hypercalcaemia, azotaemia and a normal alkali reserve. The alkaline phosphatase level was normal and the plasma phosphorus level slightly lowered.

The anorexia continued, with occasional vomiting, and the baby tended to lie rather still, making no attempt to lift herself up. Treatment with sulphamezathine in a dosage of $1.5 \mathrm{~g}$. per day in four divided doses caused a mild sensitivity rash after 10 days, and a slight rise in the blood urea level was recorded after 14 days. Again, there was no crystalluria or haematuria. When the baby was discharged from hospital at the age of 10 months the pyuria had fallen to 21 cells per c.mm. and she weighed $11 \mathrm{lb}$. Though pyuria and bacilluria were intermittently present, she began to gain weight slowly, and from 13 months of age the blood urea and serum calcium levels fell steadily to normal, though occasional serum calcium values were still raised. She developed a hypochromic microcytic anaemia which was treated by blood transfusion, and after courses of chloramphenicol and terramycin the urinary tract infection was gradually controlled. When last seen at 18 months of age she weighed $18 \mathrm{lb}$. $5 \mathrm{oz}$. but appeared quite normal apart from her smallness.
Case 3. R.R. was a second child, born normally after a full-term, normal pregnancy whose birth weight was $7 \mathrm{lb}$. $12 \mathrm{oz}$. He had been breast fed only for the first two weeks of life and was admitted to hospital at the age of $6 \frac{1}{2}$ months with a history of anorexia and vomiting since 4 months of age, having thrived until then. He was not constipated and had no polyuria; though he had no polydipsia he preferred water to milk feeds. He had had a normal intake of vitamin D.

On examination he was a pale, wasted baby who had intermittent pyuria ranging up to 300 cells per c.mm., with coliform organisms cultured repeatedly from the urine. The serum calcium and blood urea levels were elevated and he was in a state of alkalosis, although when vomiting ceased temporarily and adequate hydration had been established the alkali reserve fell to normal. The plasma phosphorus was normal.

He continued to have anorexia and vomiting, though with gradually diminishing intensity, until the age of 15 months. A course of streptomycin, started three days after his admission, had no effect, and as he had become clinically worse, sulphamezathine in a dosage of $1 \mathrm{~g}$. per day in four divided doses, with potassium citrate, was started. After a further week, during which time he had become extremely ill, severe azotaemia was noted, with hyperphosphataemia and a temporary fall in the serum calcium to normal levels; the biochemical changes are recorded in Fig. 1. No haematuria or

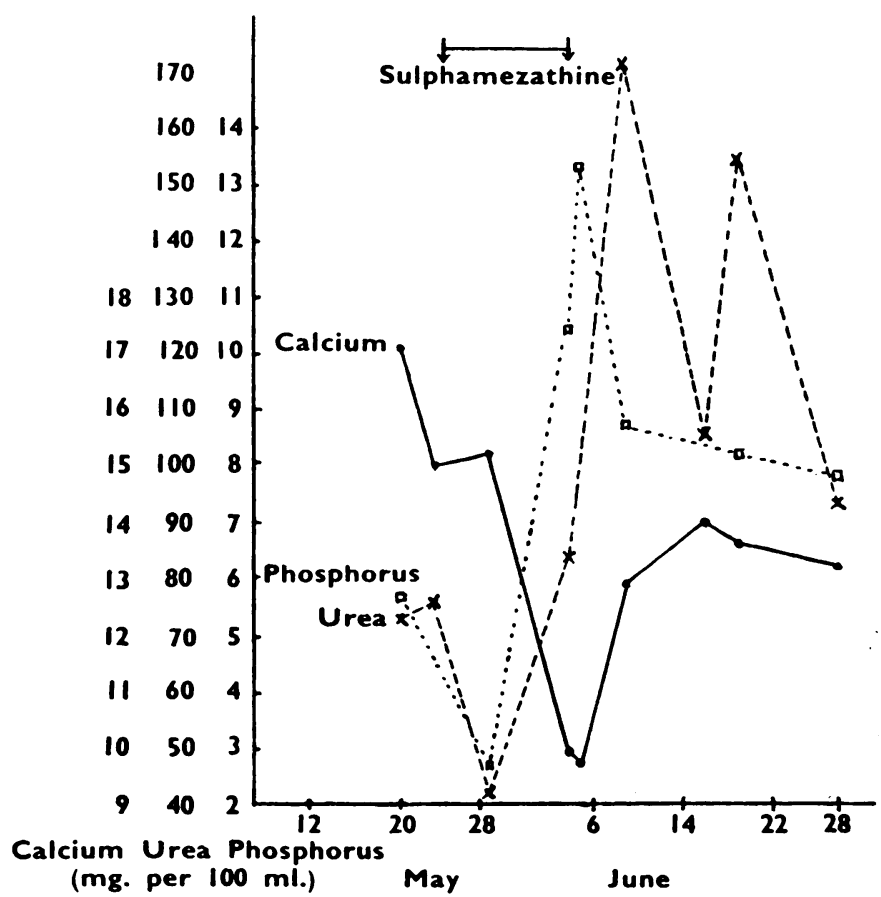

Fig. 1.-Blood biochemical changes in patient R.R. following sulphamezathine therapy. 

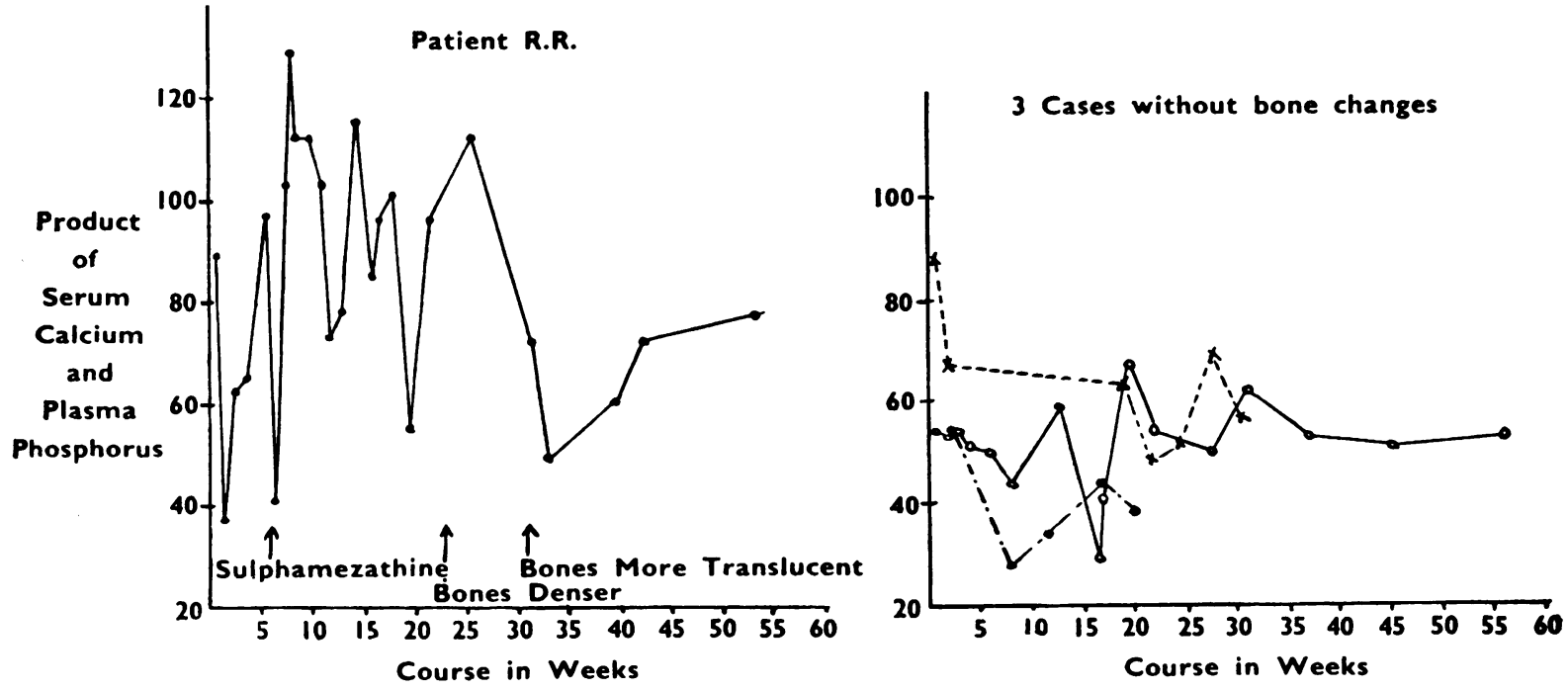

FIG. 2.-Calcium-phosphorus products in patient R.R. compared with three cases of idiopathic hypercalcaemia without comparable bone changes.

crystalluria was observed, though frequent microscopical examinations of urine were made. Following this, though the serum calcium returned to its former high levels within a few days, the blood urea level remained elevated and the plasma phosphorus level was raised for four months. As bacilluria and pyuria persisted, chloramphenicol was given, with little improvement and then a course of terramycin, after which pyuria and bacilluria gradually disappeared.

He developed a normochromic, normocytic anaemia, the haemoglobin being $9 \cdot 2 \mathrm{~g}$. per $100 \mathrm{ml}$. At 11 months of age he weighed only $13 \mathrm{lb} .3 \mathrm{oz}$. and at this age, on a fluid intake of $1 \frac{1}{2} \mathrm{oz}$. per lb. over 24 hours, the specific gravities of 11 specimens of urine were not higher than 1,010. At the time of writing he is 21 months old, weighs $17 \mathrm{lb} .4 \mathrm{oz}$. and still has hypercalcaemia and azotaemia. Though he appears to be mentally normal he has only recently begun to sit unaided.

The radiological changes in the bones are described below. Radiographs of bones of five other cases of idiopathic hypercalcaemia in infants studied in Newcastle showed no abnormality other than growth lines in four.

The bone changes were bilateral and symmetrical and the first changes were seen at 1 year, by which time he had had a markedly elevated serum calcium-phosphorus product for four months. The distal end of the ulna was cupped and of the radius irregular in outline, with single, dense transverse lines at the ends of these bones. The vertebrae looked denser than normal but radiographs of the skull were not taken at this stage.

At 13 months of age radiographs of the hands, taken for the first time, in the same film as a normal control, showed single, dense transverse bands at the distal ends of the metacarpals and at the proximal ends of the proximal phalanges.
At 14 months of age radiographs were taken of the legs. These showed obvious growth lines at the upper ends of the tibia and fibula and the upper and lower ends were cupped. The lower femoral epiphysis had a thin surrounding halo of more translucent bone, sharply demarcated from the central nucleus of bone which was densely calcified (Fig. 3). Radiographs of the skull

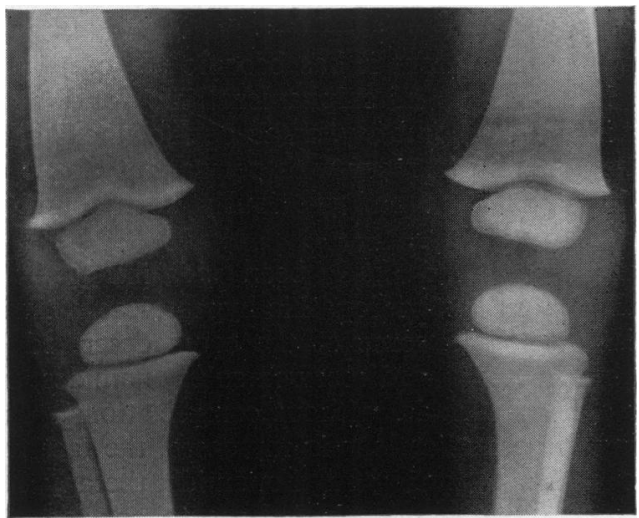

FIG. 3.-Radiograph of legs in patient R.R. showing dense epyphysea 1 centres and translucent surrounding bone. Bone at ends of metaphyses is more translucent. Some failure of tubulation is present in the distal third of the femur.

showed considerable increase in density at the base compared with a normal control (Fig. 4).

At 18 months of age radiographs of the legs showed more growth lines and the halo of translucent bone was wider in the lower femoral epiphysis, and had appeared in the upper tibial epiphysis. Adjacent to the dense transverse bands at the ends of these bones were areas 
of more translucent bone, corresponding with the epiphyseal halos, showing that recently formed bone was less densely calcified. Similar epiphyseal halos and areas of more translucent bone at the ends of the metaphyses were present at the lower end of the humerus and the upper end of the radius. Radiographs of the vertebrae now showed that the bodies were so dense that the paired nutrient foramina in each body showed up in contrast. The increased density at the base of the skull was now even more obvious.

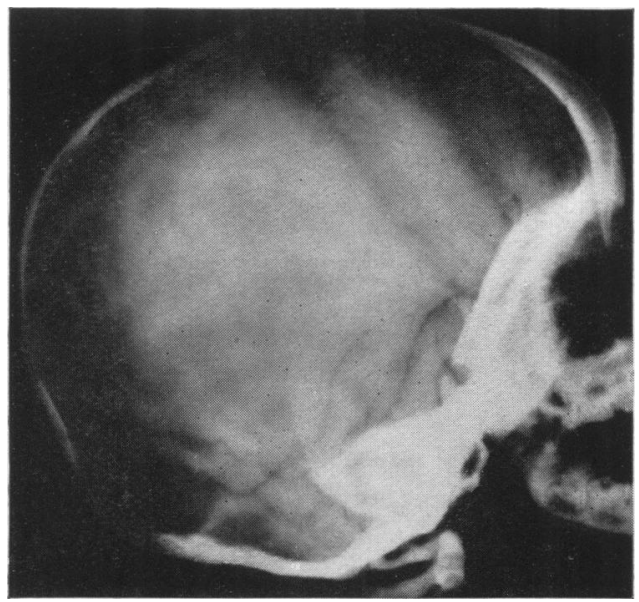

FIG. 4.-Radiograph of skull in patient R.R. showing marked thickening at the base.

\section{Comment}

In this department it has become the custom to give long courses of sulphamezathine for urinary tract infections in infancy, on account of the liability of the infection to recur with permanent effects on the kidneys. This had previously been found to be a safe procedure.

Sulphamezathine had been administered to another infant with idiopathic hypercalcaemia with no ill effect, and some of the cases described by Lightwood (1952) had received sulphonamides, but over shorter periods, without complications. Following the complications in my cases, the fact that toxic effects following sulphonamide therapy had not been noted previously led me to consider the possible effect on the kidneys of the sodium citrate given to patient J.W. and the potassium citrate given to patient R.R. In the case of J.W., on the day before alkali therapy was discontinued, a blood urea value was lower than it had been, but had risen to $246 \mathrm{mg}$. per $100 \mathrm{ml}$. seven days later. The alkali reserve, over this seven-day period, had fallen from $29.5 \mathrm{mEq}$. per litre to $22.5 \mathrm{mEq}$. per litre. Thus, though the alkali reserve had risen to abnormal levels it was not accompanied by increased azotaemia at that time. The evidence suggests that the alkali therapy did not play an important role in the causation of the increased renal damage. In the case of R.R. there was no alkalosis while the potassium citrate was being given so that the drug played no obvious part in the increased renal dysfunction in this case either.

It is difficult to advance evidence as to how sulphamezathine caused such severe renal dysfunction. It is unfortunate that blood levels were not estimated as it seems likely that renal excretion of the drug was impaired and one would therefore have expected high blood levels. In each case the toxic effects were only observed after a long course of the drug, on the tenth day in O.B., after 11 days in R.R. and after 14 days in J.W., though in the latter cases biochemical changes had certainly begun earlier. In an effort to explain the bone changes in patient R.R., the products of serum calcium and plasma phosphorus in his case were compared with those of three other cases of the same syndrome in which similar bone changes did not occur (Fig. 2). This comparison showed the product to be very much higher over a long period of time in the case with the striking bone changes.

The sequence of events in patient R.R. seems to be as follows. Sulphamezathine aggravated existing renal dysfunction with resulting hyperphosphataemia. After an initial fall, the serum calcium returned to its former high levels and the calciumphosphorus product remained persistently and markedly raised for a period of four months, at the end of which time sclerotic changes were first definitely noted though some earlier radiographs had been suspicious. After a further two months, and after a gradual fall in the calcium-phosphorus product, the density of recently formed bone diminished. It is therefore suggested that the osteosclerosis in this case may be the direct result of increased calcification due to a high product of serum calcium and plasma phosphorus.

It would seem unwise to treat with sulphamezathine any infant of the age of about 3 to 8 months in whom the symptoms suggest this illness, unless biochemical investigations have excluded it. If a short course of treatment is given the infection is liable to recur, and if a long course is given, severe toxic effects may result. It is important, therefore, that a practitioner should be familiar with the clinical picture.

\section{Clinical Picture}

In most cases this illness starts suddenly in a healthy infant of either sex, of 3 to 8 months of age. Occasionally, however, the first symptoms may 
follow another illness such as an intussusception or an upper respiratory infection. The first symptoms are anorexia and vomiting. The anorexia is characteristically worse for solid feeds, which are resolutely refused, and water or other clear fluids are preferred to milk. Often milk feeding has to be carried out by means of a spoon and even then several efforts are sometimes required to induce the infant to swallow a single mouthful. This type of anorexia may provide an important clue to the diagnosis though it is also present in renal acidosis, with which this disease is sometimes combined. Thirst and apparent polyuria may be noted by the mother but they are not presenting features of the illness. Constipation is a common finding and may be severe, with the passage of hard, pebble-like stools for several months. The infant is usually contented but may have periods of irritability when the vomiting is severe.

As the disease progresses the complexion becomes pale or greyish, the child loses weight, and the mother may note that the infant has become pale and floppy and the limbs soft. She may state further that though he appears to be normal mentally he has not begun to sit up at the normal age. In cases in which the urinary tract infection has been treated, usually after two to five months, but sometimes after a longer period, a steady weight begins, the body tone improves and the child begins to sit up. In most cases recovery is eventually complete and full health restored by the age of 18 months. A fatal outcome is most unusual but one out of seven patients studied at Newcastle died rather suddenly. A necropsy was not obtained.

On clinical examination in the acute stage of the disease one is confronted by a wasted, limp infant who nevertheless displays interest in his surroundings. In contrast with the thin extremities the abdomen may appear full and this may be accounted for by constipation and muscular hypotonia. There are often palpable faecal masses in the colon. Signs of dehydration, though usually present, are not sufficiently marked to warrant intravenous therapy; in fact the wasting is a more striking feature. The musculature is soft and the tone reduced but the tendon reflexes are brisk. Dentition is normal. A hypochromic microcytic anaemia may be present but this generally occurs late in the course of the disease. Mild intermittent pyrexia is often found. Pyuria is extremely common but is not invariably found and when it is coliform organisms are usually intermittently cultured. If proteinuria is noted it is generally slight. The hypercalcaemia is independent of the level of plasma phosphorus, which is normal or slightly lowered. The calcium and phosphorus changes in patient R.R. provide the first instance of a reciprocal relationship in my experience of the disease, the fall in serum calcium being apparently secondary to the rise in phosphorus. Since one of the theories of the syndrome is that calcium excretion is diminished as a result of renal dysfunction, with resultant hypercalcaemia, this fall in serum calcium with a known exacerbation of renal damage is not in accord with the theory, unless in this particular case other mechanisms which lower the level of the serum calcium were also operating.

\section{Summary}

Of three cases of idiopathic hypercalcaemia of infancy, receiving sulphamezathine therapy for urinary tract infections, two developed a severe and one a mild degree of azotaemia. In one child, moderate azotaemia was still present 13 months later.

In the same child, as a result of renal dysfunction, a rise in plasma phosphorus occurred, causing a markedly elevated product of serum calcium and plasma phosphorus, which persisted for four months. Sclerotic changes developed in the bones of this patient and it is suggested that the high calciumphosphorus product was responsible for this.

The clinical features of the illness are described, with a warning against the use of sulphamezathine for the commonly associated urinary tract infection.

It is a pleasure to thank Sir James Spence for his help and encouragement; Dr. S. Whateley Davidson for his help with the radiology; Dr. F. K. Herbert for her advice and for the biochemical estimations; Drs. G. Neligan, J. Stansfeld and J. Webb for access to the records of three cases which are not described here but which contribute to the clinical picture.

\section{BIBLIOGRAPHY}

Creery, R. D. G. (1953). Lancet, 2, 17.

Fanconi, G. and Girardet, P. (1952). Helv. paediat. Acta, 7, 314. Lightwood, R. (1952). Archives of Disease in Childhood, 27, 302 Payne, W. W. (1952). Ibid., 27, 302.

Schlesinger, B., Butler, N. and Black, J. (1952). Helv. paediat. Acta, $\mathbf{7}, 335$.

Stansfeld, J. M. and Webb, J. K. G. (1953). Archives of Disease in Childhood, 28, 386. 